\title{
Drilling, Construction, Geologic, and Caliper Logs for Well 8-4010-01, Kaumana Exploratory Well, Island of Hawaii
}

By Charles J. Ewart

U.S. GEOLOGICAL SURVEY

Open-File Report 98-641

Prepared in cooperation with the

DEPARTMENT OF WATER SUPPLY

COUNTY OF HAWAII 


\section{U.S. DEPARTMENT OF THE INTERIOR \\ BRUCE BABBITT, Secretary}

U.S. GEOLOGICAL SURVEY

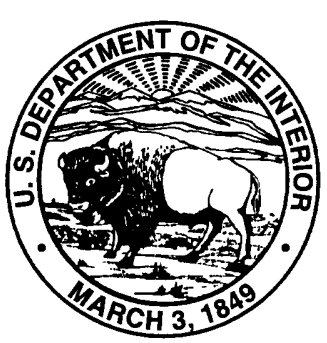

Charles G. Groat, Director

The use of firm, trade, and brand names in this report is for identification purposes only and does not constitute endorsement by the U.S. Geological Survey.

For additional information write to:

Copies of this report can be purchased from:

District Chief

U.S. Geological Survey

U.S. Geological Survey

677 Ala Moana Blvd., Suite 415

Branch of Information Services

Honolulu, HI 96813

Box 25286

Denver, CO 80225-0286 


\section{CONTENTS}

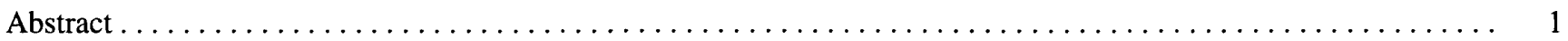

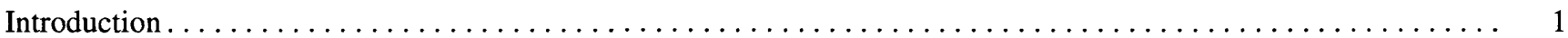

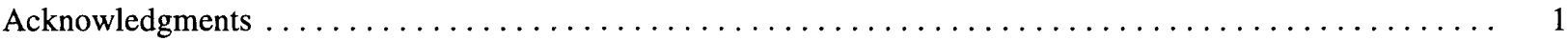

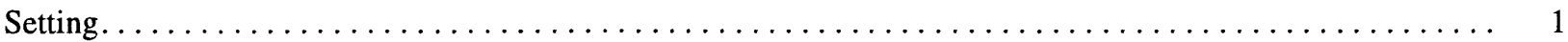

Ground-Water Occurrence. . . . . . . . . . . . . . . . . . . . . . . . . . . . . . . . .

Drilling, Construction, Geologic, and Caliper Logs for the Kaumana Exploratory Well (State Well Number 8-4010-01) 2

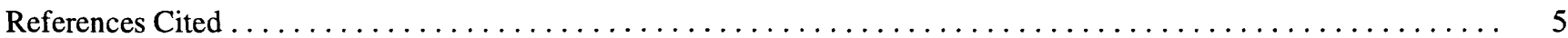

Figures

1-3. Maps showing:

1. The Hawaiian islands, island of Hawaii, and South Hilo District . . . . . . . . . . . . 3

2. The Kaumana exploratory well (State well number 8-4010-01), island of Hawaii. . . . . . . . . . 4

3. Selected wells, springs, and tunnels, South Hilo District, island of Hawaii . . . . . . . . . . 6

4. Diagram showing construction details of the Kaumana exploratory well (State well number 8-4010-01),

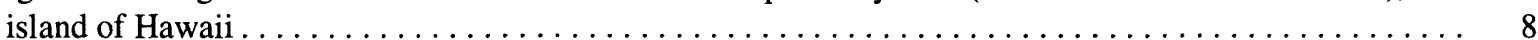

5. Graph showing caliper log for the Kaumana exploratory well (State well number 8-4010-01), island of Hawaii

\section{Tables}

1. Information for selected drilled wells in the South Hilo District, island of Hawaii . . . . . . . . . . .

2. Construction data for the Kaumana exploratory well, island of Hawaii $\ldots \ldots \ldots \ldots$

3. Geologic $\log$ for the Kaumana exploratory well, island of Hawaii $\ldots \ldots \ldots \ldots$

4. Driller's log of Kaumana exploratory well, island of Hawaii $\ldots \ldots \ldots \ldots \ldots$

\section{Conversion Factors}

\begin{tabular}{rll}
\hline Multiply & By & To obtain \\
\hline foot (ft) & 0.3048 & meter \\
gallon (gal) & 3.785 & liter \\
million gallons per day (Mgal/d) & 0.04381 & cubic meter per second \\
mile (mi) & 1.609 & kilometer \\
inch (in.) & 25.4 & millimeter \\
\hline
\end{tabular}

Elevations in this report are referenced to mean sea level. 


\title{
Drilling, Construction, Geologic, and Caliper Logs for Well 8-4010-01, Kaumana Exploratory Well, Island of Hawaii
}

\author{
By Charles J. Ewart
}

\section{Abstract}

The Kaumana exploratory well (State well number 8-4010-01) was drilled about 2 miles west of the community of Kaumana and at the western end of the Kaumana Estates subdivision. The well is located on Hawaii County land at a Department of Water Supply tank at an elevation of 1,799 feet. The well was drilled into the rocks of the Mauna Loa Volcano to a depth of 1,397 feet and encountered a water table standing at an elevation of 997 feet. Well-construction data, geologic log, driller's $\log$, and caliper log are presented for the well. This well is one of three exploratory wells drilled on the island of Hawaii between September 1994 and April 1995 in cooperation with the County of Hawaii Department of Water Supply.

\section{INTRODUCTION}

The Kaumana exploratory well was the second of three deep exploratory wells drilled on the island of Hawaii between September 1994 and April 1995. These wells were drilled by the U.S. Geological Survey (USGS) as part of a program of exploratory/monitor well drilling carried out in cooperation with the County of Kauai Department of Water, the County of Hawaii Department of Water Supply, and the City and County of Honolulu Board of Water Supply. The program, begun in 1993, is designed to provide hydrologic and geologic information for aquifers on each of the island counties. This information is vital to the understanding of the ground-water systems on each island and for estimating the amount of available ground water.

In addition to providing needed hydrogeologic information, the exploratory wells completed under this program will be used as long-term monitoring sites to provide data and information for the management, protection, and conservation of the ground-water resources. The rotation of the drilling rig between the islands and the duration of drilling on each island are determined by the three county water managers. Drilling sites are selected and prioritized jointly by the county water departments and the USGS.

The purpose of the Kaumana exploratory well was to provide information on the little known ground-water resources of the Kaumana area. The well was drilled on County of Hawaii property at the site of the Department of Water Supply's Kaumana tank at an elevation of $1,796 \mathrm{ft}$, and about $2 \mathrm{mi}$ west of the community of Kaumana and at the western boundary of the Kaumana Estates subdivision. Water was encountered at a depth of $799 \mathrm{ft}$ below land surface ( $997 \mathrm{ft}$ above sea level). This previously unknown source of high-level water may prove to be a dependable source of water for the Kaumana area which currently relies on water from several springs. The extent and nature of the impounding structures are not known. This report presents a summary of the existing knowledge of the occurrence of ground water within the South Hilo District and geohydrologic data and construction details of the well.

\section{Acknowledgments}

The USGS gratefully acknowledges the assistance of the Hawaii County Department of Water Supply in site preparation and logistical support throughout the period of well construction.

\section{Setting}

The South Hilo District of the island of Hawaii lies partly on the northeastern slopes of Mauna Loa and 
partly on the eastern slopes of Mauna Kea and has a land area of 250,900 acres (fig. 1). Elevations within the District range from sea level to $6,000 \mathrm{ft}$. Mean annual rainfall ranges from about $140 \mathrm{in}$. in coastal areas to about 300 in. in a lateral band from the Wailuku River north to Honomu, then diminishes to about $80 \mathrm{in}$. at the 6,000 -ft elevation. The Kaumana exploratory well (State well number 8-4010-01) is located at a Department of Water Supply tank site at the western boundary of the Kaumana Estates subdivision about $2 \mathrm{mi}$ west of the community of Kaumana and at an elevation of 1,796 $\mathrm{ft}$ (fig. 2). The rocks of the South Hilo District are from the Mauna Loa Volcano south of the Wailuku River and from the Mauna Kea Volcano north of the river. The historic lava flows of 1855 and 1881 from Mauna Loa Volcano extend into the southern part of the District with the 1881 flow almost reaching the sea. The Kaumana exploratory well was drilled through the 1881 lava flow into older rocks of the Mauna Loa Volcano. Mauna Loa rocks are generally highly permeable while those of Mauna Kea are of moderate to high permeability (Stearns and Macdonald, 1946).

\section{GROUND-WATER OCCURRENCE}

Ground-water occurrence in the South Hilo District has been described in detail by Stearns and Macdonald (1946), Davis and Yamanaga (1968), and summarized by Davis and Yamanaga (1973). The following generalized description of ground-water occurrence draws extensively from these works.

Within the South Hilo District, ground water is found as basal water, which is that roughly lens-shaped body of freshwater near sea level floating on seawater, and as high-level water manifested as numerous springs, most of which issue between 1,000 and 2,000 ft on the flanks of both Mauna Loa and Mauna Kea. Water from the springs is held up by ash beds, by soil formed on weathered lavas, and by dense lava flows. The perching bodies are thin and discontinuous and discharge from the springs fluctuates greatly with rainfall. There is thought to be high-level ground water held up by volcanic dikes in the interiors of Mauna Loa and Mauna Kea but there is no visible evidence of this type of occurrence within the South Hilo District. Recharge to the basal water body is from direct infiltration of rainfall on the permeable rocks and from subsurface discharge of high-level ground-water bodies. Recharge to the high-level ground-water bodies is from direct infiltration of rainfall. Discharge from the basal water bodies is from springs and seeps visible near the coast or discharging below sea level offshore and by discharge to streams where the steam channel has cut deep enough into the rocks to intersect the basal water table. Discharge from high-level ground-water bodies is from springs and seeps and from sub-surface leakage to basal water bodies.

The largest and most accessible freshwater supply can be found in the basal water body underlying the South Hilo District. Discharge from the basal water body near Hilo averages more than $100 \mathrm{Mgal} / \mathrm{d}$, and comes from springs that discharge into Waiakea pond. Because of the occurrence of springs at elevations between 1,000 to $2,000 \mathrm{ft}$, the flow can be delivered by gravity to places of need at lower elevations. This favorable occurrence is offset by the fluctuating flow volume in response to rainfall and the scattered nature of the springs, and the generally small volume.

The Kaumana exploratory well (State well number 8-4010-01) was drilled through rocks of the Mauna Loa Volcano to a depth of $1,397 \mathrm{ft}$. High-level ground water was encountered at an elevation of $997 \mathrm{ft}$ above sea level. The extent of this high-level ground-water body and the nature of the impounding structures are not known.

Information on selected drilled wells is given in table 1. Drilled wells and other sources of water in the South Hilo District are shown in figure 3.

\section{DRILLING, CONSTRUCTION, GEOLOGIC, AND CALIPER LOGS FOR THE KAUMANA EXPLORATORY WELL (STATE WELL NUMBER 8-4010-01)}

The Kaumana exploratory well was drilled by an air-rotary drill rig using a mixture of water, drilling foam, and polymer as the drilling fluid to stabilize the borehole and to aid in the removal of cuttings and water. Samples of the materials penetrated by the bit were obtained at $5 \mathrm{ft}$ intervals down to a depth of $95 \mathrm{ft}$. Circulation was lost at this depth and never regained for the remainder of the drilling to total depth. Drilling began on December 6, 1994 and was completed on February 14,1995 . Drilling was hindered by the lost circulation and by several zones of cascading water. These zones of 


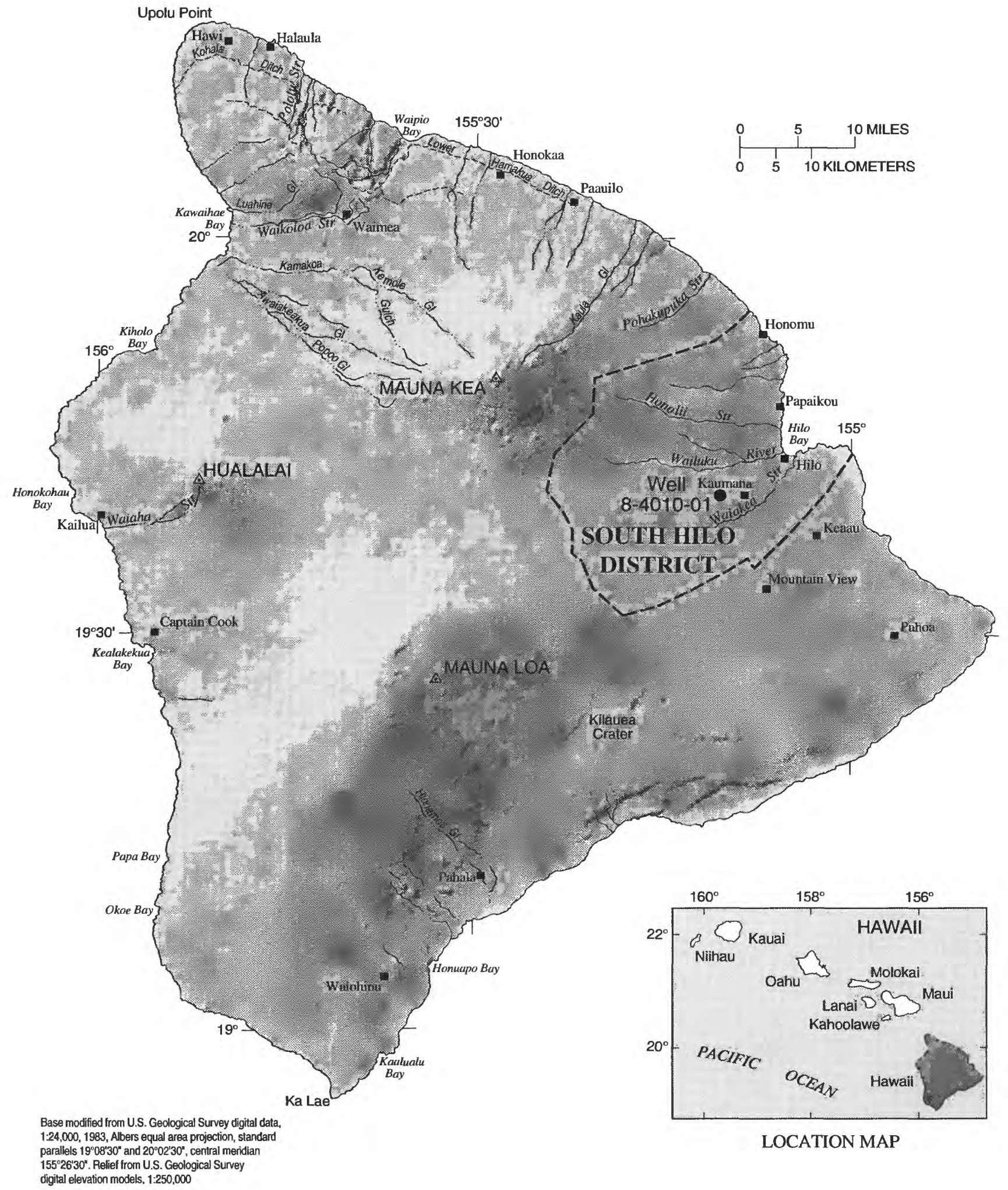

Figure 1. Location of Hawaiian islands, island of Hawaii, and South Hilo District. 


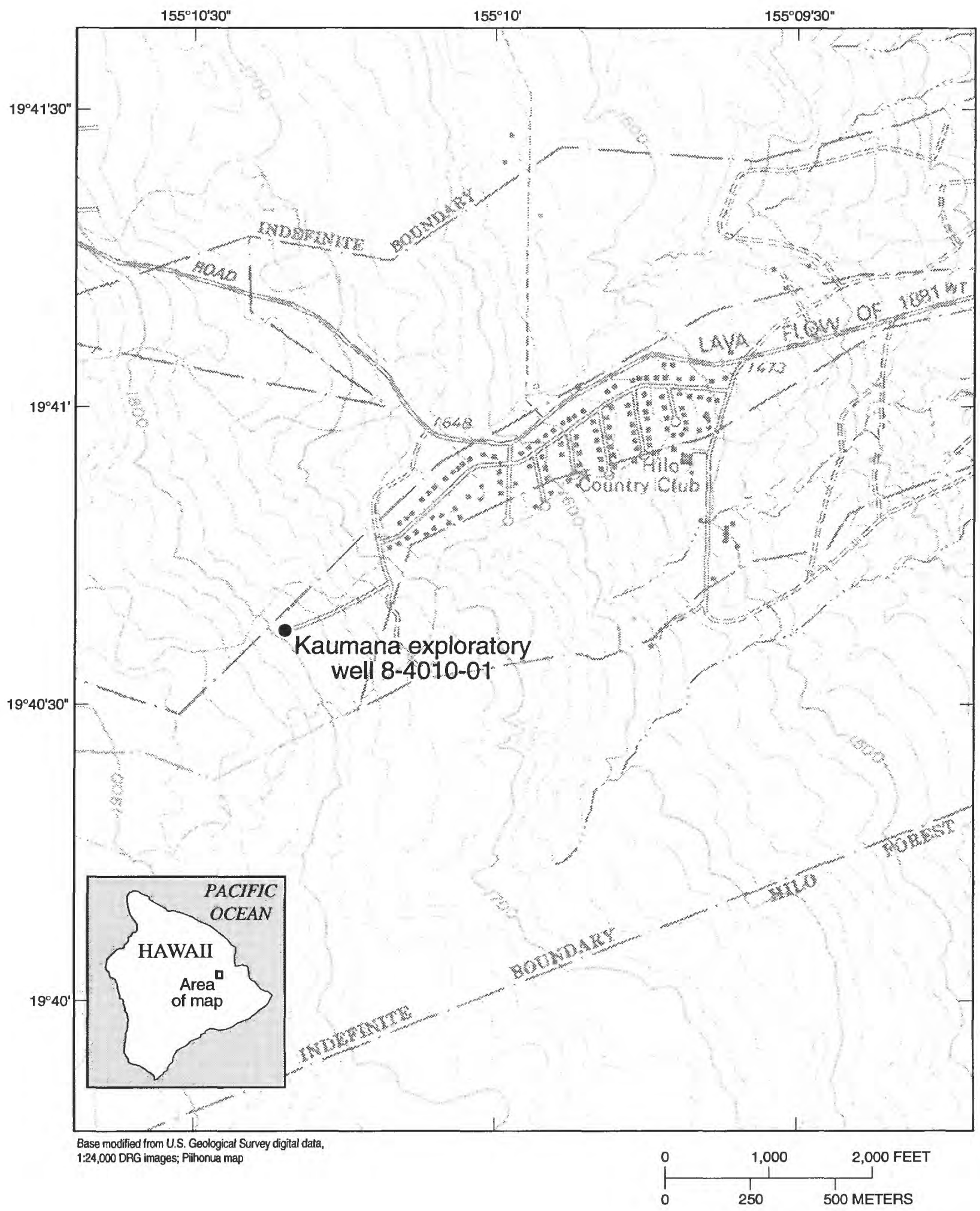

Figure 2. Location of the Kaumana exploratory well (State well number 8-4010-01), island of Hawaii. 
Table 1. Elevation, water-level, and chloride-concentration data for selected drilled wells in the South Hilo District, island of Hawaii

[Datum is mean sea level; data from records in the district office of the U.S. Geological Survey, Hawaii; --, no data]

\begin{tabular}{ccccc}
\hline $\begin{array}{c}\text { State well } \\
\text { number }\end{array}$ & Year drilled & $\begin{array}{c}\text { Elevation } \\
\text { (feet) }\end{array}$ & $\begin{array}{c}\text { Water level } \\
\text { (feet) }\end{array}$ & $\begin{array}{c}\text { Chloride } \\
\text { concentration } \\
\text { (milligrams per liter) }\end{array}$ \\
\hline $8-3844-01$ & 1987 & 552 & 33 & 12 \\
$8-3810-01$ & 1900 & 2,100 & - & - \\
$8-4003-01$ & 1963 & 206 & 13 & 8 \\
$8-4010-01$ & 1,796 & 997 & - \\
$8-4100-01$ & 1995 & 47 & 6 & 280 \\
$8-4202-01$ & 1971 & 59 & 4 & 108 \\
$8-4203-04$ & 1944 & 47 & 7 & 11 \\
$8-4203-10$ & 1961 & 55 & 6 & 13 \\
$8-4203-13$ & 1973 & 23 & 3 & 13 \\
$8-4203-15$ & 1948 & 81 & 9 & 21 \\
$8-4304-01$ & 1987 & 12 & 0.7 & 5,600 \\
$8-4306-01$ & 1941 & 278 & 42 & 2 \\
$8-4706-01$ & 1973 & 369 & 21 & 4 \\
$8-5005-01$ & 1972 & 304 & 11 & 16 \\
$8-5005-05$ & 1946 & 74 & 7 & 285 \\
$8-5006-01$ & 1977 & 378 & 12 & 7 \\
$8-5307-02$ & 1976 & 101 & 80 & - \\
\hline
\end{tabular}

cascading water were observed by a video log of the well made on January 13, 1995. A 12-1/4 in. hole was drilled to a depth of $90 \mathrm{ft}$ and an 8-in. inside-diameter steel casing grouted in place. The remainder of the hole was drilled using a 6-3/4 in. tricone tungsten carbide bit. Well-construction data are provided in table 2 and construction details are shown in figure 4.

Finally, the hole was cased with 4-in. inside-diameter, flush joint, steel casing. Blank casing was installed to a depth of $732 \mathrm{ft}$ and slotted casing was installed from 732 to $1,375 \mathrm{ft}$. Prior to the installation of the 4.5 -in. outside-diameter casing, $22 \mathrm{ft}$ of the hole was lost because of caving. A $4 \mathrm{ft}$ by $4 \mathrm{ft}$ by 4 in. concrete pad was constructed around the well, and the well was secured with a locking cover.

A geologic log of the first $95 \mathrm{ft}$ of the well is found in table 3 and a driller's log is given in table 4 . The caliper $\log$ (fig. 5) was made after reaching the final depth of $1,397 \mathrm{ft}$. The caliper tool is a means to indirectly measure hole diameter and smoothness. The tool has three 16-inch spring-loaded arms that are extended when the tool reaches the bottom of the hole. As the tool is slowly raised, a logging unit records the extension of the arms as they drag against the walls of the borehole. The maximum extension of the caliper arms is 32 in.

A video log of the borehole from ground surface to a depth of $405 \mathrm{ft}$ is available at the USGS Hawaii District Office. The log showed that water was cascading into the hole at depths below ground of 158, 200, 240, $249,317,384$, and $405 \mathrm{ft}$.

\section{REFERENCES CITED}

Davis, D.A., and Yamanaga, George, 1968, Preliminary report on the water resources of the Hilo-Puna area, Hawaii: Hawaii Division of Water and Land Development, Department of Land and Natural Resources, Circular C45, $38 \mathrm{p}$.

Davis, D.A., and Yamanaga, George, 1973, Water resources summary, island of Hawaii: Hawaii Division of Water and Land Development, Department of Land and Natural Resources, Report R47, 42 p.

Stearns, H.T., and Macdonald, G.A., 1946, Geology and ground-water resources of the island of Hawaii: Hawaii Division of Hydrography Bulletin 9, 363 p. 


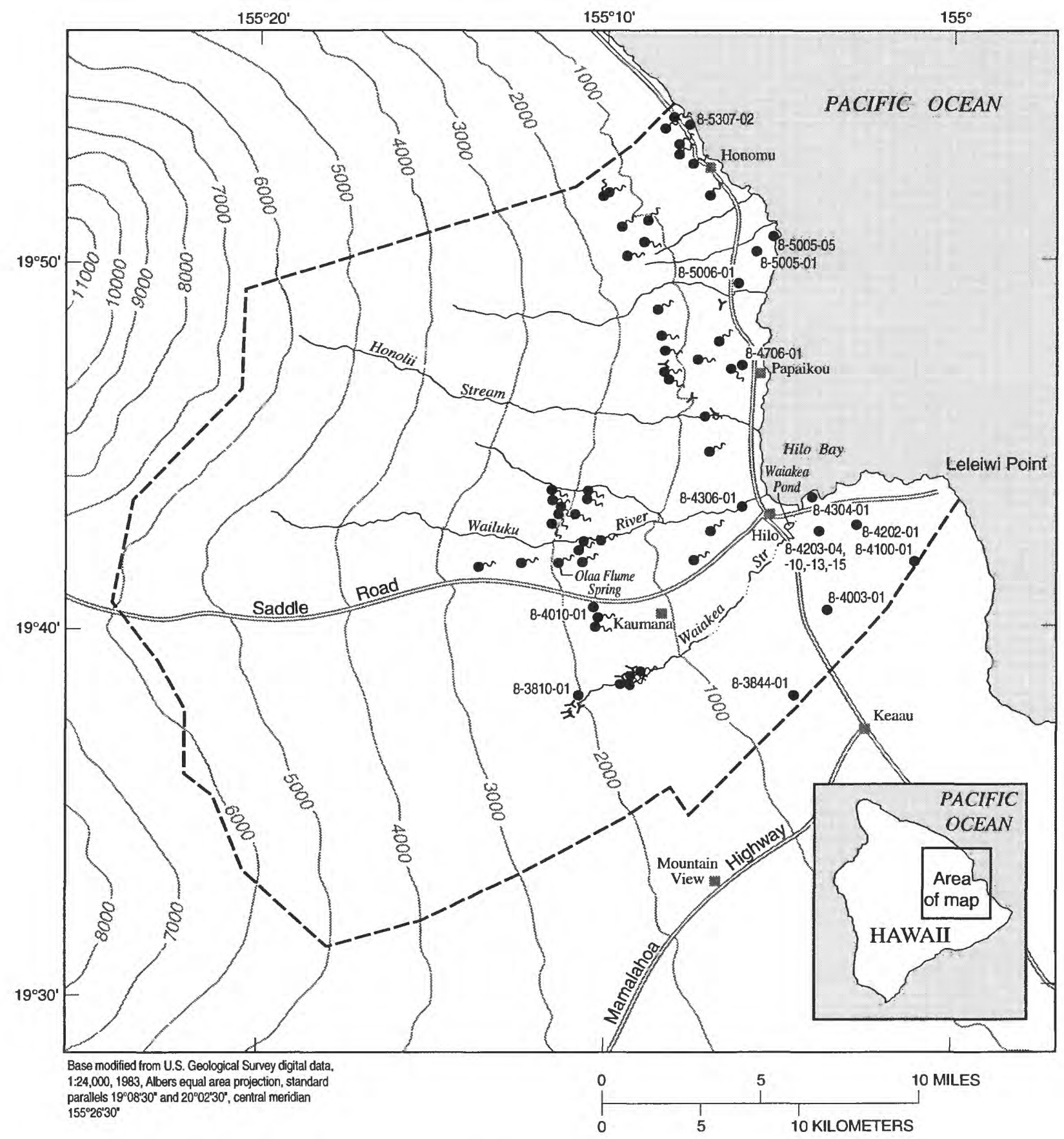

EXPLANATION

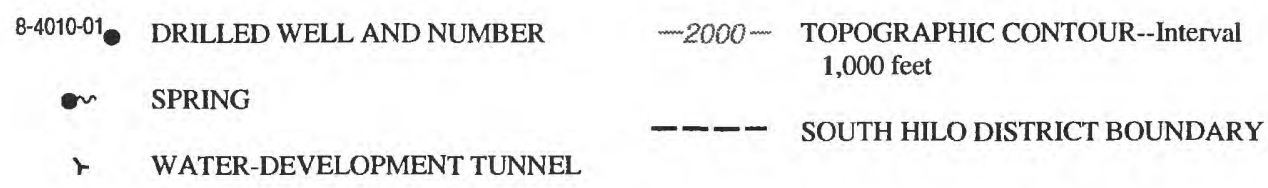

Figure 3. Selected wells, springs, and tunnels, South Hilo District, island of Hawaii. 
Table 2. Construction data for the Kaumana exploratory well, island of Hawaii [Elevation datum is mean sea level; in., inches; ft, feet; id, inside diameter; USGS, U.S. Geological Survey]

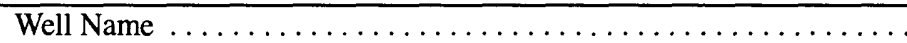

State well number.

Latitude and longitude

Hawaii tax map key number.

Landowner

Well completed

Driller

Surface hole diameter

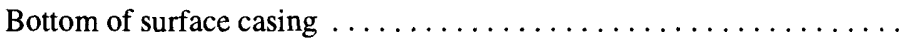

Surface casing type and diameter $\ldots \ldots \ldots \ldots \ldots \ldots \ldots \ldots \ldots$

Final hole diameter.

Bottom of well elevation.

Inner casing type and diameter.

Slotted interval elevations.

Reference mark elevation (plate in concrete pad).

Measuring point (top of 4-in. casing)

Water level and date of measurement.
Kaumana exploratory well

8-4010-01

$19^{\circ} 40^{\prime} 35^{\prime \prime} 155^{\circ} 10^{\prime} 23^{\prime \prime}$

2-5-002:024

Hawaii County

February 14, 1995

G. Wayne Heick, USGS

$12-1 / 4$ in.

$1,706 \mathrm{ft}$

Steel, 0.188-in. wall, 8-in. id

6-3/4 in.

$399 \mathrm{ft}$

Steel, 4-in. id

1,064 to $421 \mathrm{ft}$

$1,796.10 \mathrm{ft}$

$1,796.29 \mathrm{ft}$

$997.0 \mathrm{ft}$; February 13, 1995 


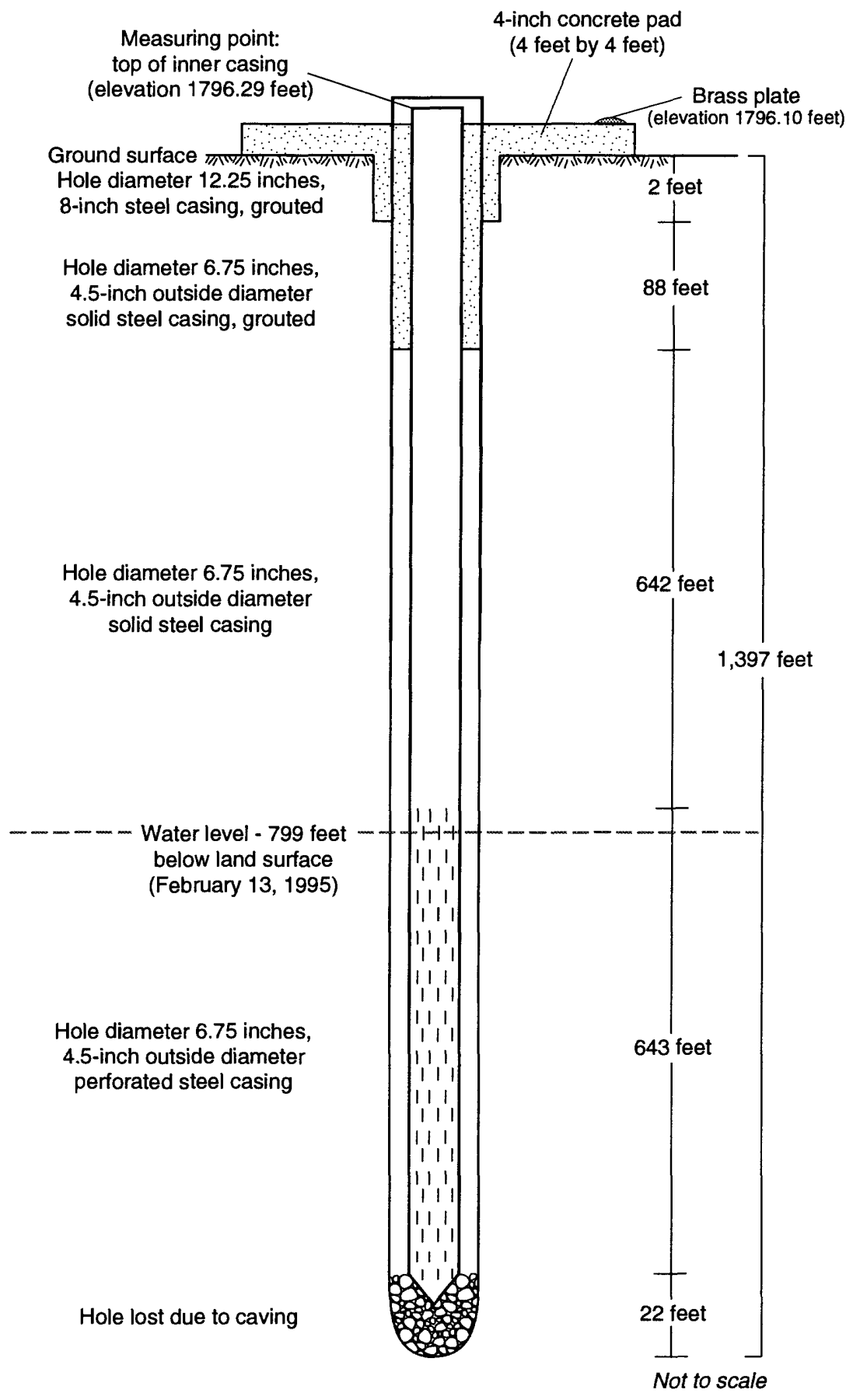

Figure 4. Construction details of the Kaumana exploratory well (State well number 8-4010-01), island of Hawaii. 
Table 3. Geologic log for the Kaumana exploratory well (State well number 8-4010-01), island of Hawaii

\begin{tabular}{cll}
\hline $\begin{array}{c}\text { Depth } \\
\text { (in feet) }\end{array}$ & \multicolumn{1}{c}{ Sample description } & Geologic description \\
\hline $0-9$ & gray, moderately vesicular, aphanitic basalt & lava flow of 1881 \\
$9-17$ & weathered, yellowish-brown ash & ash \\
$17-20$ & slightly weathered, light gray, sparsely vesicular aphanitic basalt & pahoehoe lava flow \\
$20-25$ & no sample & pahoehoe lava flow \\
$25-30$ & weathered, light-gray, highly vesicular aphanitic basalt & pahoehoe lava flow \\
$30-35$ & moderately weathered, light-gray, vesicular aphanitic basalt & pahoehoe lava flow \\
$35-45$ & moderately weathered, light-gray, vesicular aphanitic basalt & aa lava flow \\
$45-55$ & unweathered, medium-gray, highly vesicular, aphanitic basalt & pahoehoe lava flow \\
$55-60$ & moderately weathered, light purplish-gray, vesicular aphanitic basalt & pahoehoe lava flow \\
$60-65$ & moderately weathered, light-gray, vesicular aphanitic basalt & pahoehoe lava flow \\
$65-70$ & moderately weathered, light-gray, vesicular aphanitic basalt & pahoehoe lava flow \\
$70-75$ & slightly weathered, medium-gray, sparsely vesicular aphanitic basalt & pahoehoe lava flow \\
$75-85$ & unweathered, medium-gray, highly vesicular, aphanitic basalt & pahoehoe lava flow \\
$85-95$ & unweathered, medium-gray, highly vesicular, aphanitic basalt & \\
$95-1,397$ & no sample &
\end{tabular}

Notes: Circulation ended at 95 feet and never regained Samples collected by: G. Wayne Heick, Kimo Akina, and Frederick Thibedeau

Sample type: Cuttings from rotary drilling with foam and polymer

Sample repository: USGS Hawaii District office, 677 Ala Moana Blvd., Suite 415, Honolulu, HI 96813

Geologic descriptions by: S.K. Izuka, U.S. Geological Survey

Date of logging: January 1996 
Table 4. Driller's log for the Kaumana exploratory well (State well number 8-4010-01), island of Hawaii

[gal/min, gallons per minute; Drill crew--G. Wayne Heick, Kimo K. Akina, Frederick Thibedeau; circulation lost at $95 \mathrm{ft}$ and never regained]

\begin{tabular}{|c|c|c|}
\hline Date & $\begin{array}{l}\text { Depth } \\
\text { (feet) }\end{array}$ & Log/remarks \\
\hline \multirow{5}{*}{$12 / 6 / 94$} & $9-17$ & Red clay, soft, moist \\
\hline & $24-25$ & Fractured rock, wet spot \\
\hline & $25-82$ & Blue rock, solid, uniform, good returns \\
\hline & $82-85$ & Brownish-red, solid, good returns \\
\hline & $92-95$ & Blue rock, void, lost circulation \\
\hline \multirow[t]{17}{*}{$12 / 7 / 94$} & $95-98$ & Lava tube, (void) no returns \\
\hline & $98-102$ & Aa rock, medium hard \\
\hline & $102-112$ & Red oxidized rock, medium soft \\
\hline & $112-137$ & Blue rock, medium hard \\
\hline & $137-142$ & Blue rock, pahoehoe?, solid \\
\hline & $171-174$ & Lava tube, (void), tools fell, some water \\
\hline & $174-183$ & Blue rock, hard \\
\hline & $183-189$ & Red, oxidized, very broken, soft \\
\hline & $189-190$ & Puka rock, clinkers, broken \\
\hline & $190-193$ & Blue rock, solid, medium-hard \\
\hline & $193-198$ & Red clay, soft, possible water \\
\hline & $198-200$ & Red oxidized, soft \\
\hline & $200-202$ & Clinker material, soft, water at $200 ?$ \\
\hline & $202-203$ & Red oxidized, soft cinder or clay seams \\
\hline & $203-229$ & Blue rock, solid, medium hard \\
\hline & $229-234$ & Red oxidized rock, soft \\
\hline & $234-249$ & Blue rock, medium-hard \\
\hline \multirow{12}{*}{$12 / 15 / 94$} & $300-328$ & Red oxidized rock, medium-soft \\
\hline & $328-330$ & Void, tools dropped, no clinkers \\
\hline & $330-334$ & Blue rock, medium hard \\
\hline & $334-338$ & Broken, soft rock \\
\hline & $338-351$ & Red, oxidized, broken, soft \\
\hline & $351-373$ & Blue rock, medium-hard \\
\hline & $373-388$ & Red oxidized, soft, possible water \\
\hline & $388-410$ & Blue rock, hard \\
\hline & $410-430$ & Broken, soft rock \\
\hline & $430-440$ & Blue rock, hard \\
\hline & $440-456$ & Broken, soft, clay $451-456$ feet, water? \\
\hline & $456-475$ & Blue rock, medium-hard \\
\hline \multicolumn{2}{|l|}{$12 / 16 / 94$} & Strip tools, attempt to get water level, water cascading in hole, no luck \\
\hline \multicolumn{2}{|l|}{$12 / 28 / 94$} & $\begin{array}{l}\text { Caliper log hole twice, no water in hole, added new bit ran tools into hole, clean hole of } \\
\text { about } 3 \text { feet of cuttings }\end{array}$ \\
\hline \multirow[t]{4}{*}{$12 / 29 / 95$} & $475-484$ & Blue rock, hard \\
\hline & $484-486$ & Void, tools dropped \\
\hline & $486-490$ & Blue rock, medium-hard \\
\hline & $490-500$ & Red oxidized rock, soft \\
\hline
\end{tabular}


Table 4. Driller's log for the Kaumana exploratory well (State well number 8-4010-01), island of Hawaii--Continued [gal/min, gallons per minute; Drill crew--G. Wayne Heick, Kimo K. Akina, Frederick Thibedeau; circulation lost at $95 \mathrm{ft}$ and never regained]

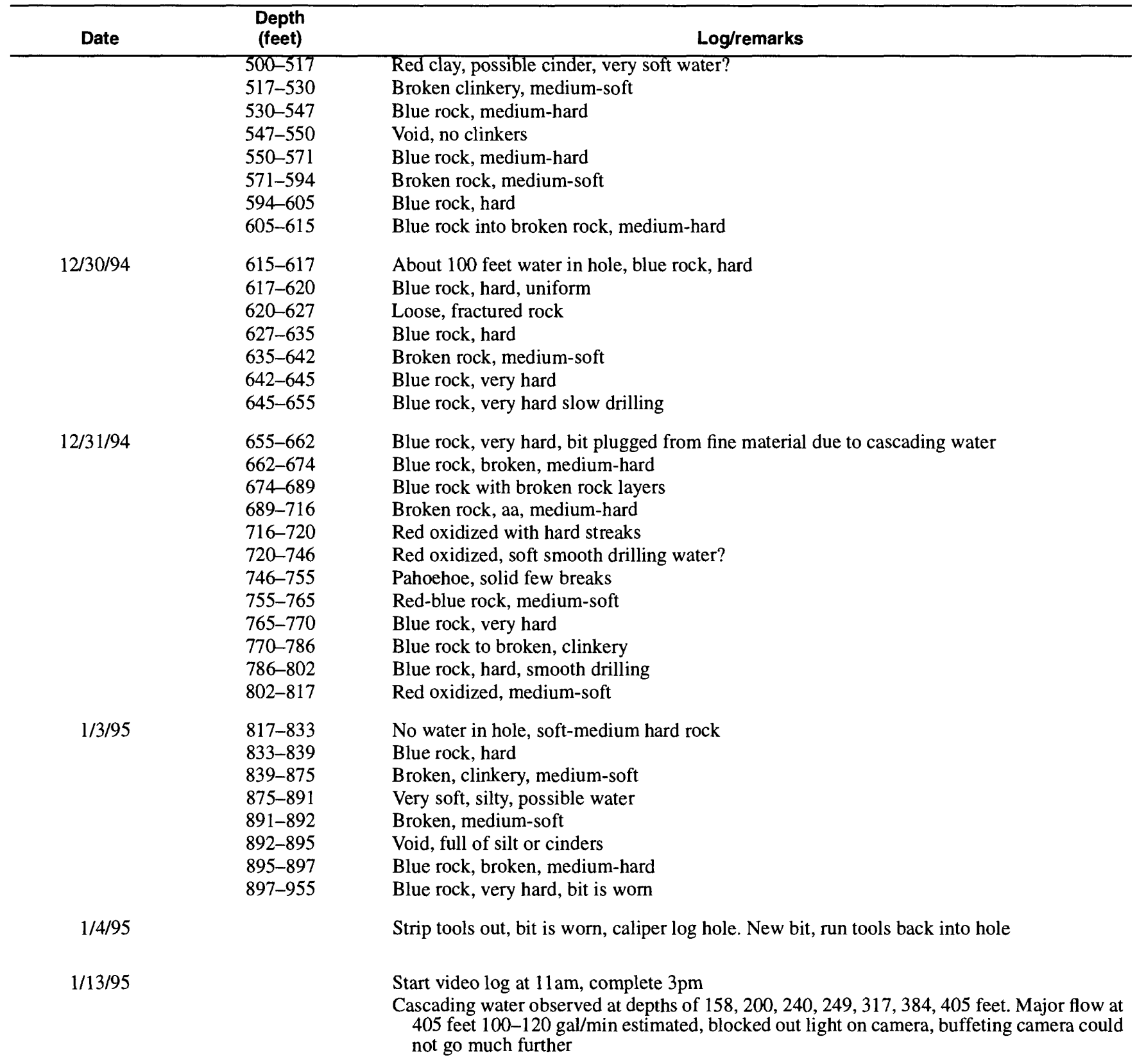

Heavy rains with some lightning, unsafe, secured site

$1 / 15 / 95$

Ran steel back in hole, checked on static water level through drill pipe, found at depth of 650 feet. More lightning and heavy rain. Unsafe to work secured site at $2 \mathrm{pm}$

Bridge in hole from cascading water. Added one joint of steel, rotated clear, static water level at 662.4 feet below table. More rain

Strip out tools to check water level, level at 662.5 below table. Checked air test shows 665 feet. All tools out for 4-day break condition hole 
Table 4. Driller's log for the Kaumana exploratory well (State well number 8-4010-01), island of Hawaii--Continued [gal/min, gallons per minute; Drill crew--G. Wayne Heick, Kimo K. Akina, Frederick Thibedeau; circulation lost at $95 \mathrm{ft}$ and never regained]

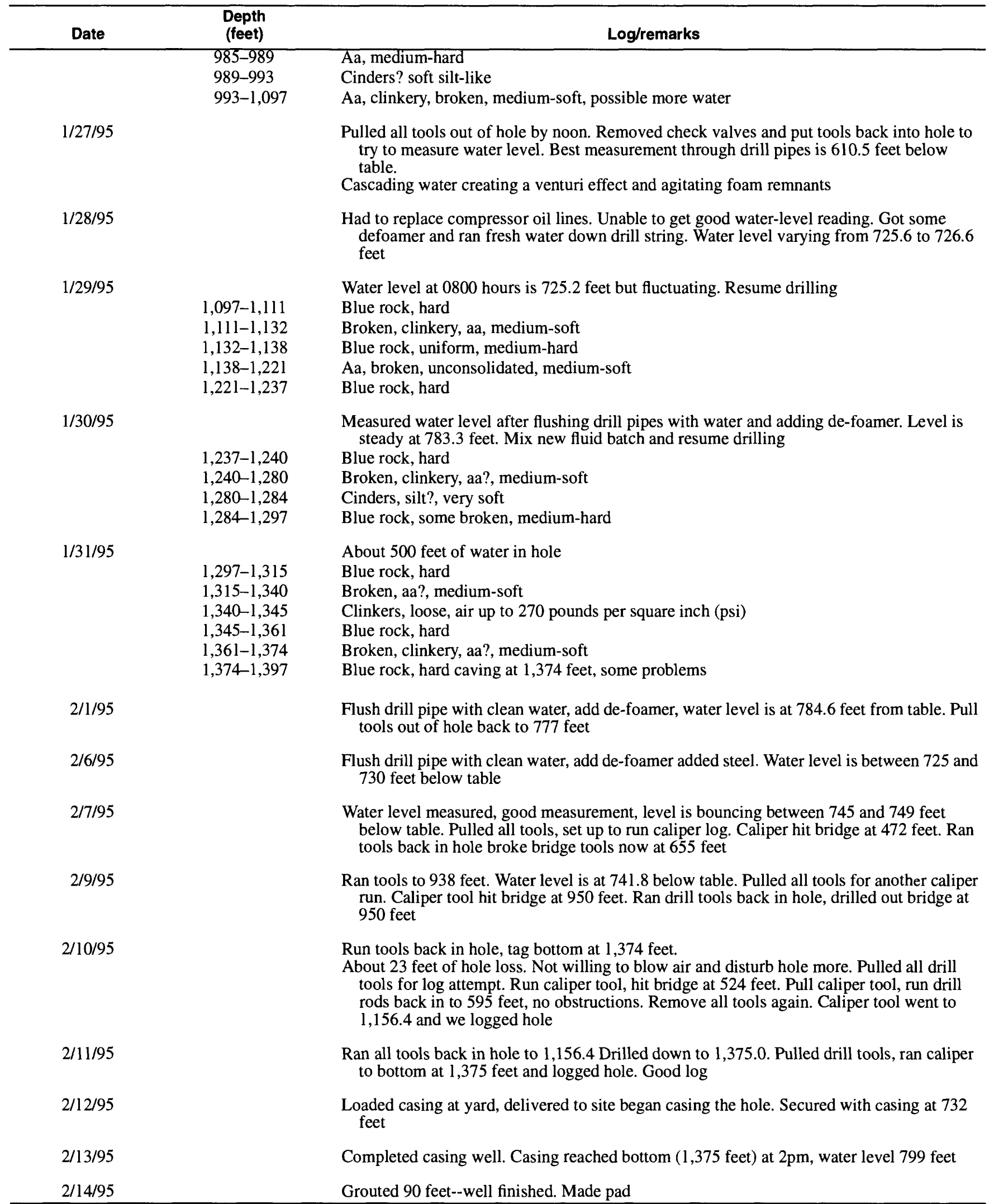




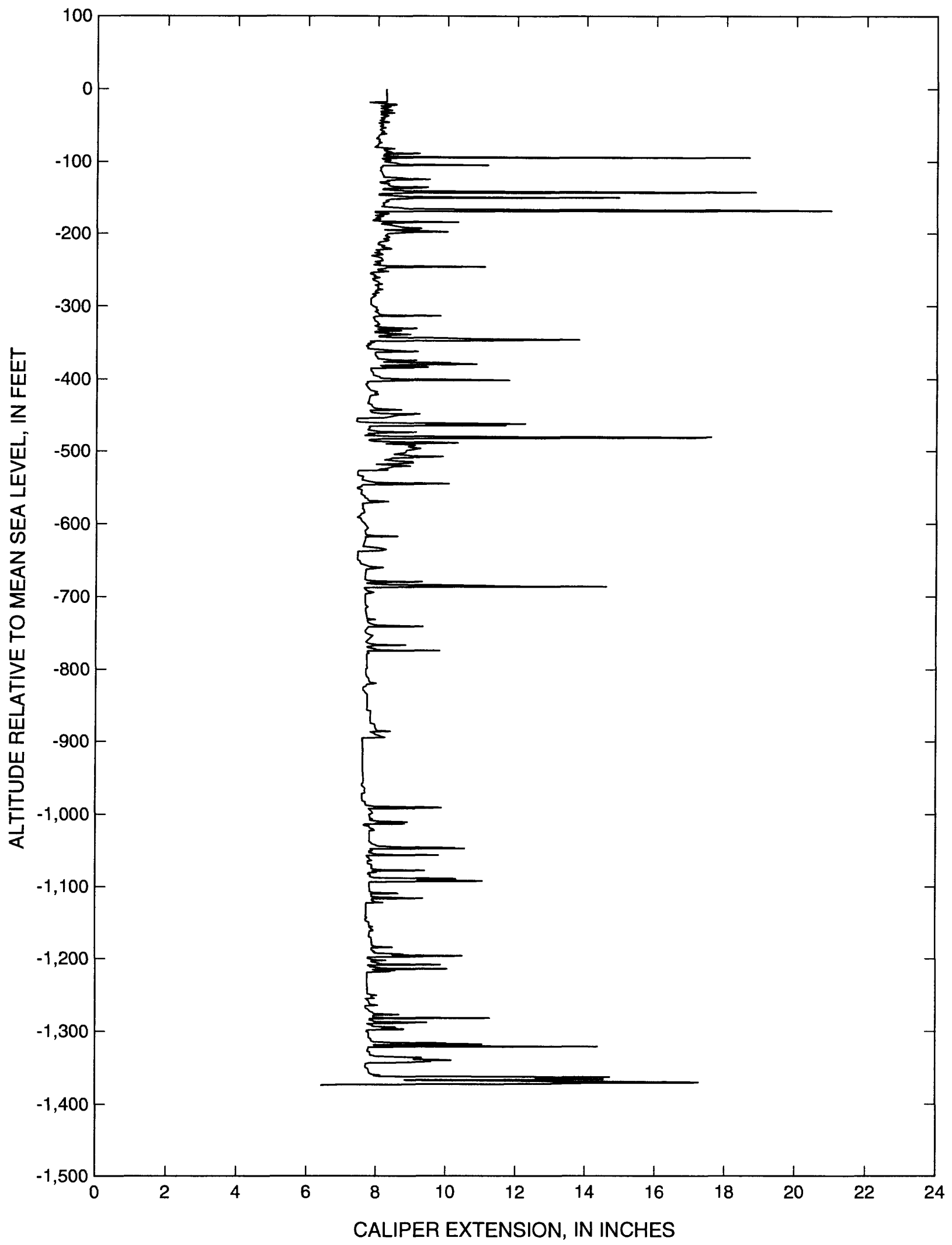

Figure 5. Caliper log for the Kaumana exploratory well (State well number 8-4010-01), island of Hawaii. 